\title{
RELAXATION EFFECT OF ETHANOLIC EXTRACT OF AVERRHOA BILIMBI L. LEAVES ON ILEUM SMOOTH MUSCLE CONTRACTION OF IN VITRO ISOLATED RAT (RATTUS NORVEGICUS)
}

\author{
RULIA MEILINA, EDY SUWARSO*, AMINAH DALIMUNTHE \\ Department of Pharmacology, Faculty of Pharmacy, Universitas Sumatera Utara, Medan, Indonesia. Email: Parikesit5252@gmail.com
}

Received: 07 March 2018, Revised and Accepted:25 March 2018

ABSTRACT

Objective: The study was aimed to investigate the relaxation effect of ethanolic extract of Averrhoa bilimbi L. leaves (EEABL) and ondansetron against 5-HT-induced contraction of the 5 - $\mathrm{HT}_{3}$ receptor.

Methods: The study of the relaxation effect of the cumulative concentration EEABL leaves $(0.5-4 \mathrm{mg} / \mathrm{mL}) \mathrm{and}$ ondansetron $\left(10^{-5}-3 \times 10^{-2}\right)$ after the contracted with 5-HT (EC80: $1.158 \times 10^{-6} \mathrm{M}$ ) was conducted in vitro using isolated rat's ileum organ in the Tyrode solution.

Results: The EEABL and ondansetron decreased ileum contraction after induced by 5 - HT. EEABL has no difference in terms of ability as ondansetron in reducing the ileum smooth muscle contraction induced by $5-\mathrm{HT}(\mathrm{p}>0.05)$.

Conclusion: The EEABL has relaxation effect on smooth muscle of rat's isolated ileum which has induced by 5-HT.

Keywords: Averrhoa bilimbi L., Serotonin (5-HT), 5-HT ${ }_{3}$ receptor, Ethanolic extract.

(C) 2018 The Authors. Published by Innovare Academic Sciences Pvt Ltd. This is an open access article under the CC BY license (http://creativecommons. org/licenses/by/4. 0/) DOI: http://dx.doi.org/10.22159/ajpcr.2018.v11s1.26588

\section{INTRODUTION}

Averrhoa bilimbi Linn. is found in Asia [1]. Although a native of Malaysia and Indonesia, it is a widely cultivated tree in southern India, particularly in Mangalore and Udupi [2]. A. bilimbi leaves have been widely used as traditional medicine to treat a cough, itches, boils, and diarrhea. A. bilimbi studied have a pharmacological antibacterial activities [3,4], antidiabetic activity [1,5], antioxidant activities [6], apoptogenic effects [2], and antihyperlipidemic activity [1].

Diarrhea is still a health problem in the world, the increase of morbidity every year, 2 billion cases occur every year and as many as 1.9 million children under 5 years died from diarrhea [7,8]. Serotonin (5-HT) is an important signaling molecule in the gut targeting enterocytes, smooth muscles, and enteric neurons. In physiological studies of gut smooth muscle, 5-HT can make the bowel contract, depending on the experimental conditions [9]. 5-HT increases in diarrhea and decreases in constipation [10].

Indonesia has great biodiversity that potential for the discovery of new drugs. Therefore, it is possible to find a new alternative treatment for diarrhea from natural resources. Although A. bilimbi has been used traditionally by the community as a medicine such as for diarrhea, the scientific data associated with pharmacological activity reports were still lack.

In the current study, the relaxation effect of ethanolic extract of $A$. bilimbi L. leaves (EEABL) on ileum smooth muscle was evaluated.

\section{MATERIALS AND METHODS}

Materials

Drugs and chemicals used in this study were serotonin, ondansetron, dimethyl sulfoxide (Sigma-Aldrich, USA), and ethanol 96\% (Merck, Indonesia). Instrument used in this experiment was organ bath PowerLab (ML0146/50, PanLab, AD Instruments, New Zealand).

\section{Preliminary phytochemical screening}

A. bilimbi L. was collected from Medan, North Sumatera, Indonesia, and identified by Indonesian Institute of Sciences, Research Center for
Biology (No:1151/IPH.1.01/If.07/IV/2017). Phytochemical screening was carried out on $A$. bilimbi L. leaves powder to determine the constituents, which include alkaloid, flavonoids, glycosides, saponins, tannins, triterpenoids, and steroids [11,12].

\section{Preparation of extract}

A. bilimbi L. leaves were washed and dried at $30-35^{\circ} \mathrm{C}$, then grinded until dried powder was obtained. The dried powder was percolated using ethanol $96 \%$, then the obtained percolate was evaporated.

\section{Tissue preparation}

Male rat weighing 200-300 g (2-3 months) was housed in a room with controlled temperature and lighting and allowed free access to chow and water. The experimental protocol of this study was evaluated by Animal Research Ethics Committees, Universitas Sumatera Utara (No: 246/TGL/KEPK FK USU-RSUP HAM/2017). The animals were sacrificed by cervix dislocation. The intestine was dissected out and the mesenteric coating was gently removed. Subsequently, the ileum was cut with a length of 1-5 cm with which connected to the transducer MLT0201 (PanLab, AD Instrument) connected with PowerLab T15- 0676 (PanLab, AD Instrument) [13].

The contraction of ileum smooth muscle induced by 5-HT Serotonin testing was performed to measure the maximum extent of rat ileum contraction to obtain $\mathrm{EC}_{80}$. Following 60-min equilibration, the ileum smooth muscle strips were contracted with series concentration $\left(10^{-8}\right.$ $10^{-4} \mathrm{M}$ ) of 5-HT (agonists). After the contraction reached a maximum, the tissue strips were washed by fresh Tyrode solution in the same condition for $60 \mathrm{~min}$ (with replacement of the Tyrode solution every $15 \mathrm{~min}$ ) [13].

The relaxation effect of EEABL and ondansetron of ileum smooth muscle induced by 5 -HT

After equilibration, rat ileum was contracted gradually with single concentration of 5-HT $\left(\mathrm{EC}_{80}\right)$ to the tissue bath as a control concentrationresponse curve until maximum contraction was achieved. The ability of EEABL and ondansetron to challenge 5-HT-induced ileum contraction was tested using cumulative addition of EEABL $(0.5-4 \mathrm{mg} / \mathrm{mL})$ and ondansetron $\left(10^{-5}-3 \times 10^{-2}\right)$. All the experiment conducted using Tyrode buffer with gas flowing $\mathrm{O}_{2}: \mathrm{CO}_{2}(95 \%: 5 \%)$ [14]. 
Statistical analysis

Log $\mathrm{EC}_{80}$ and relaxation data were analyzed using SPSS 22 version (Table 1). The contractile responses to cumulative 5-HT, EEABL, and ondansetron were analyzed using one-way analysis of variance followed by a Tukey post hoc test. All data are presented as mean \pm standard error of the mean and $p<0.05$ was considered statistically significant.

\section{RESULTS}

Phytochemical screening

Table 1 shows the Screening result of A.bilimbi L. Leave powder.

\section{Effects on the contraction of ileum induced by 5-HT}

Series concentration of 5-HT-induced the contraction on rat isolated ileum smooth muscle. Response percentage of ileum smooth muscle increased with the addition of 5-HT concentration. The maximum 5-HT concentration for ileum smooth muscle contraction was $3 \times 10^{-4} \mathrm{M}$. The next given 80 effective concentration or $\mathrm{EC}_{80}\left(1.15 \times 10^{-6} \mathrm{M}\right)$ was not change the percentage of smooth muscle contraction (Fig. 1)

The relaxation effect of EEABL and ondansetron of ileum smooth muscle induced by 5 -HT

The effect of EEABL on isolated rat ileum to the contraction induced by agonist compound could be observed through the changes of isolated ileum smooth muscle contraction \% response with the addition of EEABL $(0.5-4 \mathrm{mg} / \mathrm{mL})$ and ondansetron $\left(10^{-5}-3 \times 10^{-2}\right)$ on ileum organ.

Addition a series of concentrations of EEABL and ondansetron resulted in the relaxation effect on the contraction of smooth muscle ileum mice induced by 5 -HT $\left(1.158 \times 10^{-6} \mathrm{M}\right)$ (Fig. 2). The relaxation effect produced by ondansetron was compared with the relaxation effect of EEABL in the rat ileum that was contracted with 5 -HT. Ondansetron concentration $1 \times 10^{-5}$ has a relaxation effect of $27.3750 \pm 1.8630$ showed no statistically significant difference with the concentration of EEABL $0.5 \mathrm{mg} / \mathrm{mL}(33.3775 \pm 1.35640)$ ( $\mathrm{p}>0.05)$. Ondansetron concentration $3 \times 10^{-2} \mathrm{mg} / \mathrm{mL}$ showed maximum relaxation result of $97.59 \pm 1.40 \%$ and showed no statistically significant difference $(p>0.05)$ with EEABL concentration $3.5 \mathrm{mg} / \mathrm{mL}(100 \pm 0.00 \%)$ (Tables 2 and 3). EEABL has no statistically significant difference in terms of ability as ondansetron in reducing the ileum smooth muscle contraction induced by 5 -HT $(\mathrm{p}>0.05)$.

Table 1: Screening results of $A$. bilimbi L. leave powder

\begin{tabular}{ll}
\hline Screening & A. bilimbi L. leaves powder \\
\hline Alkaloids & - \\
Flavonoids & + \\
Glycosides & + \\
Saponins & + \\
Tannins & + \\
Triterpenoid/steroids & + \\
\hline A. bilimbi: Averrhoa bilimbi &
\end{tabular}

Table 2: The relaxation effect of EEABL after the contracted with 5-HT $\left(\mathrm{EC}_{80}: 1.158 \times 10^{-6} \mathrm{M}\right)$

\begin{tabular}{lll}
\hline EEABL concentration $(\mathbf{m g} / \mathbf{M l})$ & Relaxation (\%) & SEM \\
\hline 0.5 & 33.3775 & 1.3567 \\
1 & 47.1500 & 2.0065 \\
1.5 & 55.7704 & 2.9706 \\
2 & 70.3100 & 2,5961 \\
2.5 & 82.2600 & 1.6811 \\
3 & 88.8825 & 0.3765 \\
3.5 & 100.0000 & 0.0000 \\
4 & 100.0000 & 0.0000 \\
\hline EEABL: Ethanolic extract of Averrhoa bilimbi L. leaves, A. bilimbi: Averrhoa \\
bilimbi
\end{tabular}

\section{DISCUSSION}

5-HT administrations have increased ileum smooth muscle contraction through $5-\mathrm{HT}_{3}$ receptor stimulation. $5-\mathrm{HT}_{3}$ receptors expressed in various types of cells and this receptor cellular signal is mediated by 5 -HT $[15,16]$. These receptors play an important role in controlling the physiological response of the central and peripheral nerve activity [17].

5-HT is ligand-gated ion channel receptor, $5-\mathrm{HT}_{3}$ receptors are not selective and can be passed by $\mathrm{Na}^{+}, \mathrm{K}^{+}$, and $\mathrm{Ca}^{2+}[18]$. Activated $5-\mathrm{HT}_{3}$ receptor by $5-\mathrm{HT}$ stimulates the cholinergic nerve and release acetylcholine [9]. Acetylcholine binds to the $A C h-M_{3}$ receptor, activation of this $\mathrm{ACh}-\mathrm{M}_{3}$ receptor through $\mathrm{G}$ protein, then stimulates phospholipase $\mathrm{C}$ inducing the formation of two intracellular messengers, IP3 and diacylglycerol (DAG) $[13,19]$. Both of these compounds are the second messenger that plays an important role in increasing $\mathrm{Ca}^{2+}$ intracellular concentration $\left(\left[\mathrm{Ca}^{2+}\right]\right)$. IP3 play a role in the increased $\left[\mathrm{Ca}^{2+}\right]$ through IP3 receptor activation on sarcoplasmic reticulum so that stimulating the release of $\mathrm{Ca}^{2+}$ deposits to the cytosol $[20,21]$. DAG activates influx of calcium through opening calcium channels in cell membranes. The contraction of smooth muscle is triggered when phosphorylation of myosin light chain (MLC) occurs by MLC kinase. This kinase is activated by binding to the complex of intracellular $\mathrm{Ca}^{2+}$-calmodulin $[22,23]$

In the study, we found that EEABL inhibited the contraction of ileum smooth muscle induced by 5-HT in Tyrode solution. Relaxation effect of EEABL compared with ondansetron (5- $\mathrm{HT}_{3}$ antagonist). The finding indicates that EEABL tends to inhibit the release of intracellular $\mathrm{Ca}^{2+}$ from intracellular $\mathrm{Ca}^{2+}$ store and affect efflux $\mathrm{Ca}^{2+}$ possess. Extract indicated contained glycosides, flavonoids, saponins, tannins, and triterpenoid/steroids. The relaxation effect of EEABL indicated that the chemical compounds contained in the extracts possess inhibit the release $\mathrm{Ca}^{2+}$. Traditional plants contained flavonoids have a vasorelaxant effect [24]. Several compounds have been reported possess relaxation

Table 3: The relaxation effect of ondansetron after the

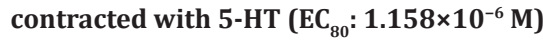

\begin{tabular}{lll}
\hline $\begin{array}{l}\text { Ondansetron concentration } \\
(\mathbf{m g} / \mathbf{M l})\end{array}$ & Relaxation (\%) & SEM \\
\hline $1 \times 10^{-5}$ & 27.3750 & 1.8630 \\
$3 \times 10^{-5}$ & 33.1800 & 2.1133 \\
$1 \times 10^{-4}$ & 45.1525 & 2.3073 \\
$3 \times 10^{-4}$ & 56.7975 & 3.0240 \\
$1 \times 10^{-3}$ & 67.2550 & 2.5957 \\
$3 \times 10^{-3}$ & 72.1325 & 0.9724 \\
$1 \times 10^{-2}$ & 85.0275 & 2.5189 \\
$3 \times 10^{-2}$ & 97.5950 & 1.4046 \\
\hline
\end{tabular}

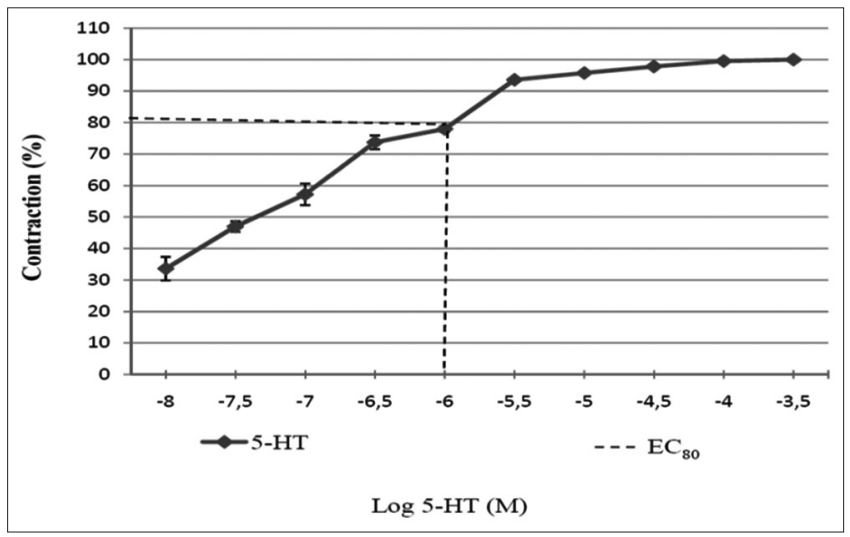

Fig. 1: Concentration-response curves to 5 -HT $\left(10^{-8} \mathrm{M}-3 \times 10^{-4} \mathrm{M}\right)$ Data presented as mean \pm standard error of mean from $n=3$ 


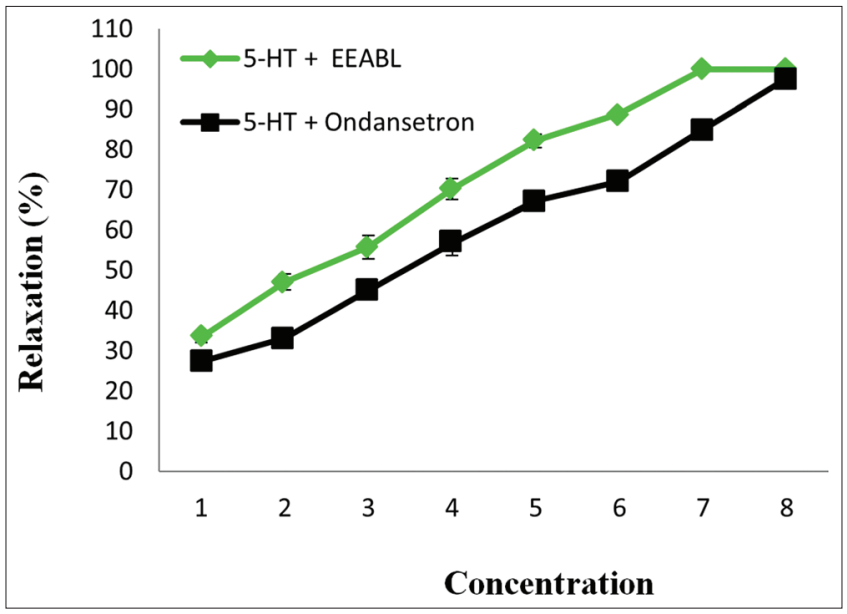

Fig. 2: The relaxation effect of ondansetron concentration compared with ethanolic extract of Averrhoa bilimbi L. concentration on smooth muscle of rat's ileum isolated induced by 5-HT (EC80: 1.158 $\times 10^{-6} \mathrm{M}$ ). Data presented as mean \pm standard error of mean from $n=5$

effect on smooth muscle muscarinic-mediated receptor such as flavonoid and flavonoids have an inhibitory effect on bladder smooth muscle contractility $[20,25]$.

\section{CONCLUSION}

The EEABL showed relaxation effect on smooth muscle of rat's ileum isolated induced by 5 -HT

\section{ACKNOWLEDGMENTS}

The authors would like to thank the head of the pharmacology and phytochemical laboratory (Faculty of Pharmacy, Universitas Sumatera Utara) for helpful support in this project research.

\section{REFERENCES}

1. Pushparaj P, Tan CH, Tan BK. Effects of Averrhoa bilimbi leaf extract on blood glucose and lipids in streptozotocin-diabetic rats. J Ethnopharmacol 2000;72:69-76.

2. Chauhan JB, Balaji K, Jayarama S, Kapfo W. Evaluation of apoptogenic effects of Averrhoa bilimbi extract on ehrlich ascites carcinoma bearing mice. Asian J Pharm Clin Res 2016;9:1-5.

3. Abdullah A, Rahman S, Islam M, Ara AB. A comparative study on antibacterial activities and cytotoxic properteis of various leaves extracts of Averrhoa bilimbi. Int J Pharm Sci Res 2014;5:913-8.

4. Sreedam CD, Sultana S, Roy S, Sheikh SH. Antibacterial and cytotoxic activities of methanolic extracts of leaf and fruit parts of the plant
Averrhoa bilimbi (Oxalidaceae). Am J Sci Ind Res 2011;2:531-6.

5. Kumar AS, Kavimani S, Jayaveera KN. A review on medicinal plants with potential antidiabetic activity. Phytomedicine 2011;2:53-60.

6. Das S. Antimicrobial and antioxidant activities of green and ripe fruits of Averrhoa carambola linn. and Ziziphus mauritiana lam. Asian J Pharm Clin Res 2012;5:102-5.

7. World Gastroenterology Organization. Acute Diarrhea. In: Adults And Children: A Global Perspective. World Gastroenterology Organisation Global Guidelines; 2012.

8. Spruill WJ, dan Wade WE. Diarrhea, Constipation, and Irritable Bowel Syndrome. In: Dipiro JT, editor. Pharmacotherapy a Pathophysiologic Approach. $7^{\text {th }}$ ed. New York: The McGraw-Hill Companies Inc.; 2008. p. 618 .

9. Sikander A, Rana SV, Prasad KK. Role of serotonin in gastrointestinal motility and irritable bowel syndrome. Clin Chim Acta 2009;403:47-55.

10. Dunlop SP, Coleman NS, Blackshaw PE, Perkins AC, Singh G, Marsden CA, et al. Abnormalities of 5-Hydroxytryptamine metabolism in irritable bowel syndrome. Clin Gastroenterol Hepatol 2005;3:349-57.

11. Ministry of Health of Republik of Indonesia. Health Profile. Jakarta: Kemenkes; 1995.

12. Harbone JB. Metode fitokimia. ITB 1987;2:6-49.

13. Nugroho AE, Anas Y, Arsito PN, Wibowo JT, Riyanto S, Sukari MA. Effects of marmin, a compound isolated from Aegle marmelos Correa, on contraction of the guinea pig-isolated trachea. Pak J Pharm Sci 2011;24:427-33.

14. Mashhadi FF, Naylor RJ, Javid FA. The effects of serotonin receptor antagonists on contraction and relaxation responses induced by electrical stimulation in the rat small intestine. Gene Cell Tissue 2014;1:e18311.

15. Lummis SCR. 5-HT 3 receptors. J Biol Chem 2012;287:40239-45.

16. Machu TK. Therapeutics of 5-HT3 receptor antagonists: Current uses and future directions. Pharmacol Ther 2011;130:338-47.

17. Thompson AJ, Lummis SC. 5-HT receptors. Curr Pharm 2006; 12:3615-30.

18. Barnes NM, dan Neumaier JF. Neronal 5-HT receptors and SERT. Tocris Biosci Sci Rev Ser 2011;34:16.

19. Penn RB, Benovic JL. Regulation of heterotrimeric G protein signaling in airway smooth muscle. Proc Am Thorac Soc 2008;5:47-5.

20. Harahap U, Husori DI, Marianne, Yuliasmi S, Patilaya P, Laila L, et al. Inhibitory effect of ethanolic extract of Curanga fel-terrae (Pugun Tano) Leaves on acetylcholine muscarinic-3 receptors induced on isolated guinea pig tracheal. Asian J Pharm Clin Res 2017;10:117-9.

21. Hall IP. Second messengers, ion channels and pharmacology of airway smooth muscle. Eur Respir J 2000;4:1120-7.

22. Semenov I, Herlihy JT, Brenner R. In vitro measurements of tracheal constriction using mice. J Vis Exp 2012;64:pii:3703.

23. Govindan S, Taylor CW. P2Y receptor subtypes evoke different $\mathrm{Ca}^{2+}$ signals in cultured aortic smooth muscle cells. Purinergic Signal 2012;8:763-77.

24. Torres-Piedra M, Figueroa M, Hernandez-Abreu O, Ibarra-Barajas M, Navarrete-Varquez G, Estrada-Soto S. Vasorelaxant effect of flavonoids through calmodulin inhibitor: Ex vivo, in vitro, and in silicoapproaches. Bioorg Med Chem 2011;19:542-6.

25. De Mey JG, van Kerrebroeck P. The inhibitory effect of the flavonoid galangin on urinary bladder smooth muscle contractility is mediated in part by modulation of $\mathrm{Ca}^{2+}$ release from intracellular stores. Planta Med 2005;71:962-4. 